\title{
The Link between Intersubjectivity and Self-Shaping in the Light of Phenomenological Philosophy
}

\author{
Bianca Bellini \\ Vita-Salute San Raffaele University in Milan \\ biancabellini@gmail.com
}

Received 21 January 2018; accepted 15 June 2018; published 30 September 2018.

\begin{abstract}
The paper aims to investigate the link between self-shaping and intersubjectivity from a phenomenological perspective. This means that two main topics are here at stake. On the one hand, the paper purports to argue that tackling the link between self-shaping and intersubjectivity from a phenomenological perspective is a meaningful $(\S 1)$ and sound approach (§2). On the other hand, the paper purports to argue that such an analysis enables us to bring to light an inherent linkage that tethers the topic of intersubjectivity to the sway that other persons hold over one's process of self-shaping. This influence will be gradually investigated. Firstly, Husserl's stance on other persons as "variations of my self" ("Abwandlungen meiner Selbst") will allow us to understand why other persons might hold sway over one's process of self-shaping and self-knowledge (§3). Secondly, exemplariness will turn out to be the way through which other persons might hold sway over one's process of self-shaping and self-knowledge: Scheler's stance on exemplariness will be examined since he makes us treat the question of exemplariness from the standpoint of the process of the formation of individuality: exemplars hold sway over such a process (\$4). So, we will rely upon the Husserlian thesis ("the other person is an intentional variation of my self"- "der Andere [ist] eine intentionale Abwandlung meiner selbst") and the Schelerian thesis (others could become exemplars for me) to argue for a thesis that goes beyond Husserl's and Scheler's perspectives: others as exemplars shed light on the eidetic possibilities of myself and others could become exemplars for me since they are variations of myself; that is, they exemplify untaken possibilities of myself. ${ }^{1} \mathrm{We}$ will argue that exemplariness is the key to the link between the issue of intersubjectivity and the process of self-shaping.
\end{abstract}

Keywords: descriptive phenomenology; eidetic possibilities; exemplariness; Husserl; individuality; Scheler; self-shaping.

\footnotetext{
${ }^{1}$ The expression "untaken possibilities of myself" is coined by the author of this paper; it does not pertain to Husserl's or Scheler's thought.
} 


\section{Introduction}

Could other persons hold sway over one's own process of self-shaping and selfknowledge? If so, how is it possible? How does such an influence play out? I continuously meet persons or just come across them. No matter whether they are real or fictitious (for example, through literary works or films), I am continuously faced with others' lives: do such encounters - real and/or fictitious - have an impact on my process of self-shaping and self-knowledge? These questions flow into the following philosophical issue: is there a link between the issue of intersubjectivity (the fact that I am continuously faced with others' lives) and the issue of self-shaping (the process of shaping my individuality)? This paper purports to answer this question by appeal to phenomenological philosophy-especially, Husserl's and Scheler's views - so as to argue for a thesis that partly relies upon the claims of these two philosophers and partly goes beyond them.

We aim to investigate the link between self-shaping and intersubjectivity from a phenomenological perspective. This means that two main topics are here at stake. On the one hand, we purport to argue that tackling the link between self-shaping and intersubjectivity from a phenomenological perspective is a meaningful $(\S 1)$ and sound approach $(\S 2)$. On the other hand, we purport to argue that such an analysis enables us to bring to light an inherent linkage that tethers the topic of intersubjectivity to the sway that other persons hold over one's process of self-shaping. This influence will be gradually investigated. Firstly, Husserl's stance on other persons as "variations of my self" (Husserl, 2012, p. 368) will allow us to understand why other persons might hold sway over one's own process of self-shaping and selfknowledge ( $\$ 3)$. Secondly, exemplariness will turn out to be the way through which other persons might hold sway over one's process of self-shaping and we will appeal to Scheler's stance on the matter (1911-1921, 1973) since he makes us treat the question of exemplariness from the standpoint of the process of formation of individuality ( $(4)$ : exemplariness is not simply a matter of admiration or emulation of actions; indeed, it is a matter of a radical influence over one's self-shaping and self-knowledge. These outcomes will set the stage for an overarching comprehension of the link between exemplariness and intersubjectivity: exemplars represent the deepest impact that others could have over one's self-shaping.

A literary exemplification could help us to better understand why the link between self-shaping and intersubjectivity demands to be examined in great detail. Let us briefly take into account Resurrection by Tolstoy, a novel in which the main character experiences a radical self-discovery and a disruptive self-change that lead him to reorchestrate himself accordingly. This literary exemplification enables us to get to the heart of the matter: the individuality of other persons is the source of the deepest impact on our process of self-shaping. Other persons and their specific individualities could radically hold sway over our individualities and such an impact flows into disruptive self-changes, as this novel clearly shows.

The novel begins with Katerina walking to the courtroom and Prince Dmitri Ivanovitch Nekhludoff being astonished to see that the defendant is Katerina. Nekhludoff recognizes her and remembers his behaviour towards her in the past: his student days, first love and his transformation from a peaceful, unselfish man to a selfish one. In fact, when Nekhludoff 
was a student at the university, he came to know Katerina and fell in love with her. Three years later, when he returned, military life had made him selfish and depraved: he seduced her and, right after, gave her money and left for his regiment. After the war, he returned and learned that she had become pregnant and gone away: somewhat relieved, he tried to forget her. At the trial, the unexpected sight of Katerina fills Nekhludoff with a mixture of loathing and pity. Gradually, he begins to feel remorse for the life to which he has driven her (the baby died and she, after a series of tribulations, became a prostitute). Because of a careless legalistic oversight by the jury, Katerina, though innocent, is sentenced to four years of hard labour in Siberia. Driven by his uneasy conscience, Nekhludoff goes to a lawyer to discuss the possibility of an appeal. The novel deals with the gradual resurrection of Nekhludoff:

one of the most widespread superstitions is that every man has his own special, definite qualities. [Indeed] the man often becomes unlike himself, while still remaining the same man. In some people these changes are very rapid, and Nekhludoff was such a man. These changes in him were due to physical and to spiritual causes. At this time he experienced such a change. (Tolstoy, 2000, pp. 210-211)

Such changes stem from the impact that others have over him. Upon returning from military life and when feeling remorse for the life to which he has driven Katerina, he experiences a disruptive change: in the passage where Tolstoy describes such changes, he stresses that "all this terrible change had come about because he had ceased to believe himself and had taken to believing others" (Tolstoy, 2000, p. 49). It is the other person that has a radical impact on my self-shaping by triggering disruptive changes. Let us pay attention to the passage where Tolstoy describes how Nekhludoff changes before and after his military life:

he then had been an honest, unselfish lad, ready to sacrifice himself for any good cause; now he was depraved and selfish, and thought only of his own enjoyment. Then God's world seemed a mystery which he tried enthusiastically and joyfully to solve; now everything in life seemed clear and simple, defined by the conditions of the life he was leading. Then he had felt the importance of [...] nature, and [...] philosophers and poets. What he now considered necessary and important were human institutions and intercourse with his comrades. Then women seemed mysterious and charming $[\ldots]$; now $[\ldots]$ women were the best means towards an already experienced enjoyment. Then money was not needed [...]; but now this allowance of 1,500 roubles a month did not suffice [...] Then he had looked on his spirit as the I; now it was his healthy strong animal I that he looked upon as himself. (Tolstoy, 2000, p. 49)

Such terrible changes came about since he did not believe in himself and had taken to believing in others:

this he had done because it was too difficult to live believing one's self; believing one's self, one had to decide every question not in favour of one's own animal life, which is always seeking for easy gratifications, but almost in every case against it. Believing others there was nothing to decide; everything had been decided already, and decided always in favour of the animal I and against the spiritual. Nor was this all. Believing in his own self he was always exposing himself to the censure of those around him; believing others he had their approval. (Tolstoy, 2000, pp. 49-50) 
Nekhludoff experiences a series of self-changes that, though differently, are all triggered by others: on the one hand, it is the presence of Katerina that makes Nekhludoff feel remorse for his past life so that "the distance [...] between what he wished to be and what he was [was enormous]" (Tolstoy, 2000, p. 109); on the other hand, he turns from an honest man to a selfish one because he started believing others and stopped believing in his own self. This is why this novel well exemplifies the radical impact that others may have on my self-shaping. We are not interested in lingering over the manners of influence that Tolstoy describes in his novel. Indeed, we regard this literary exemplification as a jumping-off point that is useful for bringing to the foreground the overarching impact that others can have on my self-shaping. Nekhludoff changes his individuality and his life in the light of others' influence: our first-person perspective experience supports this claim, but how to explain it in philosophical terms? This literary exemplification clarifies why we tackle the link between intersubjectivity and self-shaping. Specifically, we will comb through this link heeding two key questions: "how is it possible that others could hold sway over me?" and "how does such an impact play out?" So as to develop a new thesis on the matter, we will answer the first question by appeal to Husserl and the second by appeal to Scheler.

\section{How Traditional Approaches Tackle the Link between Intersubjectivity and Self-Shaping}

In this first paragraph we intend to take stock of a few traditional approaches towards the link between intersubjectivity and self-shaping so that the phenomenological contribution to this field could emerge in a clear and sound manner. How could a phenomenological account of this link enrich the current debate revolving around the same topic? To answer this question, we have to identify the blind spots of a series of approaches we often rely on to tackle the link between intersubjectivity and self-shaping. This overview enables us to understand why we will opt for a phenomenological analysis.

The first way in which we could tackle the link between intersubjectivity and self-shaping refers to the approach referred to as "virtue ethics." According to this philosophical viewpoint, the issue of intersubjectivity is inherently bound up with the issue of self-shaping insofar as our process of shaping ourselves depends upon persons who exemplify virtues. Within this framework, other persons are examples we need to follow if we aim to be virtuous. This implies that there are certain persons - like wise ones - who exemplify sets of virtues so clearly that they are pivotal benchmarks in our effort to be virtuous: a virtuous person is a living measure of human actions. As the virtuous agent acts in particular and concrete situations with practical wisdom, she overcomes the generality typical of law and, in so doing, becomes a worthy object of imitation. From this standpoint, the virtuous agent functions as a living rule and so we have to be able to recognize her as such and then imitate her. If we aim to comprehend what prudence is, for instance, then we take into account the (real or fictitious) persons that we think are prudent and try to imitate them. What this approach seems to lack refers to the individuality both of the example and the 
person who imitates the example: the influence of the former over the latter does not depend upon the specific individuality of the former and the latter. Indeed, this kind of influence is based only on the virtues that are exemplified. So, how could such an impact really hold sway over self-shaping if the issue of individuality is left outside the frame?

A second way in which we could tackle the link between intersubjectivity and self-shaping refers to the "moral imagination approach." According to this philosophical viewpoint, the issue of intersubjectivity is inherently bound up with the issue of self-shaping insofar as our process of shaping ourselves depends upon the persons - fictitious or real-who enable us to stretch the boundaries of our individuality through imagination. Others enable us to step over the restricted range of our own individualities and self-possibilities. Real persons or fictitious characters allow us to face experiences that otherwise we would never face. According to this approach, imagination is a force we appeal to in the process of selfshaping since it enables us to stretch and broaden the boundaries of personal individuality: Kirk (1981) describes moral imagination as the "power of ethical perception which strides beyond the barriers of private experience and momentary events" (Kirk, 1981, p. 38; cf. Fennel, 2016; Babbitt, 1908). Within this framework, literature works are a powerful means that allows us to "stretch" our restricted lives. For Kirk, literature is the primary vehicle for the formation of moral imagination (cf. Kirk, 1981, pp. 45-46) and literary works aim for ethical ends - they endeavour to teach us what it means to be humans, "to form the normative consciousness" (Kirk, 1981, p. 40). This does not mean that authors preach to readers: moral imagination does not make literature moralistic. Literature is supposed to make us understand enduring values - the meaning of dignity and humanity. Naturally, this normative understanding is not formed by literature only. Nonetheless, in comparison with other sources of normative consciousness-like school or church-literature turns out to be the most influential because it makes us overstep the limits of our own personal experiences, which are not enough to provide us with enduring standards.

Such theses hark back to Martha Nussbaum's stance on the link between imagination and literature in the light of the concept of moral imagination. According to her, literary works are the key to social justice because they expand our empathy and stir our moral imagination: literature encourages us to exercise moral imagination so that we sharpen our capacity to put ourselves in another person's situation. This exchange of perspectives makes us aware that those who are marginalized can no longer be dehumanized and put outside the circle of empathy. According to Nussbaum, "empathy is something we practice, and literature helps us to flex this muscle" (McRobie, 2014). The chief idea is that, thanks to literature, we can live more than one life: firstly, literary works take us to times, geographical locations, and social realities that we have not experienced yet and perhaps will never personally experience; secondly, literary works enable us to comprehend the viewpoint of others from within since we can really experience their experiences while reading. This sort of indirect experience is so powerful that we will then find hard to consider others as alien or completely different persons, however much the society we inhabit may try to draw a line to tell them apart by pointing at them as allegedly different "groups." Nussbaum regards literature as essential to our living since by exercising moral imagination we 
become more human and responsible citizens (cf. Nussbaum, 1995, p. 73): "literary works [...] invite their readers to put themselves in the place of people of many different kinds and to take on their experiences" (Nussbaum, 1995, p. 5). Literature tells us that imagining the lives of others is a daily necessity for human beings since we best learn to understand, care, and behave well with others when we learn about imagining others' lives.

So, the "moral imagination approach"-from Kirk to Nussbaum — regards imagination as a force that allows us to stretch the boundaries of our individualities so as to adopt a broader perspective that comes to include the persons that we deem as different persons. What this approach seems to lack refers to the kind of impact that others play in selfshaping: by appeal to moral imagination, others realize that my individuality is linked with theirs more than they think. Others' impact seems to be confined to this self-awareness so that this approach does not seem to account for a more radical impact that others may have on self-shaping.

A third way in which we could tackle the link between intersubjectivity and self-shaping refers to an approach that puts in the foreground the notion of "moral beauty." According to this philosophical viewpoint, the issue of intersubjectivity is inherently bound up with the issue of self-shaping insofar as other persons may bodily exemplify virtues and, subsequently, influence my moral conduct. Moral beauty consists of the bodily expression of virtues, moral qualities, and excellence of character: it pertains to the embodiment of virtues. This kind of inner beauty is subtle, difficult to discern, hard to spot. Sure, there are some virtues - courage, for example - that manifest very forcefully, but not every virtue manifests in the same way (cf. Kidd, 2017). From this perspective, there is a mode of inner beauty that consists of the outer expression of inner virtues: "it is a good thing that there are people whose moral beauty attracts us" (Zagzebski, 2017, p. 60). What this approach seems to lack relates to the kind of impact that others play in self-shaping: this impact is confined to the virtues that nourish the moral beauty of a given person. It seems that such an explanation does not make room for circumstances in which I am affected by another person, but such an impact does not depend upon the virtues that the other person exemplifies, eventually in a beautiful manner.

The fourth way in which we could tackle the link between intersubjectivity and self-shaping relates to an approach that argues for imagination's epistemic function. According to this philosophical viewpoint, the issue of intersubjectivity is inherently bound up with the issue of self-shaping insofar as the process of shaping myself depends on my effort of reflecting upon the possible versions of myself. If we take into account the stance on imagination that is typical of a few contemporary philosophers-Kind (2013a, 2013b) and Williamson (2016) - we come to realize that if we ponder over our "possible selves," we end up deeply affecting the way we act, behave and make decisions. Williamson and Kind bring to light the epistemic function typical of imagination: as persons we consist of possible selves that we need to heed when making decisions, acting, and reflecting upon future possible scenarios. Putting it very simply, if I have to decide whether to wear the red shirt or the blue one, I can just imagine myself - a possible self - wearing the first one and then 
the second one. This kind of appeal to imagination involves imagery, but we can devise cases in which such an appeal does not take place. For example, if I am uncertain whether to accept a job offer or not, I could imagine how my life would change if I accepted it. These and similar cases bring to light an epistemic function that imagination plays with regard to contingency (cf. Kind, 2013b, p. 2). Although Kind acknowledges that Sartre (1940) is right when claiming that imagining contains nothing more than what we put into it, she argues that imagination epistemically guides us through the contingency since it leads us to engage in imaginative simulations that "propel me to reach a conclusion that I had not previously believed" (Kind, 2013b, p. 18). These conclusions are not mere guesses since imagination leads us to "justify our belief in a contingent claim about the world":

would my kids be able to handle seeing The Wizard of $\mathrm{Oz}$, or would the Wicked Witch be too scary for them? [...] I imagine sitting with my kids on the couch as the Wicked Witch first appears on screen, I imagine them hearing the witch's cackle as she taunts Dorothy, and as I figure out what their reactions are going to be, I come to realize that they're not quite ready to watch that movie $[. .$.$] When we engage in these kinds of imaginative simulations,$ if things have gone right $[\ldots]$ we take ourselves to be justified in our decisions to bar our children from watching the movie. (Kind, 2013b, p. 18)

The beliefs I have regarding the world (for example, about what scared my children in the past) guide me through my imagining since "they act as constraints on my imagination" (Kind, 2013b, p. 18). Subsequently, "when I do set the right constraints, and when I am good at abiding by them, my imagining can be as epistemically relevant to my project as their imaginings are to theirs" (Kind, 2013b, p. 19). Like Kind, Williamson maintains that imagining has a role in the cognitive circuit and in devising practically relevant possibilities: "imagination has the basic function of providing a means to knowledge - and not primarily to knowledge of the deep, elusive sort that we may hope to gain from great works of fiction, but knowledge of far more mundane, widespread matters of immediate practical relevance" (Williamson, 2016, p. 113). Both Kind and Williamson agree that imagination, far from being independent of the world, relies upon one's knowledge of what the world is like: the way in which imagination is tethered to the world is the doorway to a more inclusive imagination which could be regarded as a way of being attentive to possibilities and, specifically, to the range of self-possibilities.

The reappraisal of the justificatory power of imagination leads us to argue that, for Williamson and Kind, possible variants of myself have a strong impact on my self-shaping. What this approach seems to lack refers to the range of influence that Kind's or Williamson's theses enable us to account for. Thanks to imagination I can delve into the range of my possible selves and, in so doing, I find myself affected by such possible selves: what about the influence of others regarded as "possible selves of myself"? The approach we have just examined does not address this question since it confines the justificatory power of imagination to the sphere of possibilities related to the self as myself: it does not take into account the possibilities that others may exemplify and that may have an impact on my self-shaping since they are related to my individuality. 
A fifth way in which we could tackle the link between intersubjectivity and self-shaping refers to an approach that puts in the foreground the notion of exemplarism. According to this philosophical viewpoint, the issue of intersubjectivity is inherently bound up with the issue of self-shaping insofar as others as exemplars hold sway over my own process of self-shaping. We could refer to Linda Zagzebski (2017) as a contemporary harbinger of such an approach: she outlines a moral theory that maps the primary set of moral termslike "virtue," "right act," and so on - around the features of exemplars, to whom we refer directly through the specific emotion of admiration. Moral philosophers often use a descriptivist theory of meaning for moral terms, whereas she proposes defining these terms by direct reference to exemplars of goodness. She argues that exemplars are picked out by admiration, which is a sort of natural form of learning. A good person is a supremely admirable person: admiration is a way to distinguish virtues, while disadmiration is a way to distinguish vices. Sure, an identification of exemplars is revisable, and it can be changed or adjusted. What matters is the practical side of admiration, i.e. emulation: I emulate persons I admire since I think they are exemplars, that is, they embody certain virtues that I have learned are like those persons. This entails that admiration is motivating and moral learning is grounded in emulation. So, a central power of moral exemplars is that they elicit the admiration of other persons - a positively valenced comprehension of a person's positive qualities. Zagzebski discusses three main kinds of exemplars-heroes, saints, and sages - and argues that making a set of persons rather than a set of concepts the foundation of a moral theory spots a natural way in which human beings become moral beings. Heroes, saints, and sages are characterized by different kinds of excellence and are exemplars insofar as they are admirable. Admirability is a signal that aids us in discerning that a certain person is an exemplar: the fact that I admire her is a clue of her exemplarity.

Zagzebski's reappraisal of admiration is quite remarkable since she was among the first who favoured its retrieval after a long philosophical neglect: admiration is the means by which we identify exemplars and it spurs us to emulate them. Zagzebski argues that admiration is a necessary condition for recognizing exemplars, but is admiration enough to describe the process of recognition of exemplars? Are all the persons I admire worthy of emulation? One could argue that Zagzebski's account is quite monochrome insofar as it relies upon a mere admire-and-emulate model. Regardless of this, what this approach seems to lack refers to the individuality of the exemplar and the person who is affected by the exemplar: Zagzebski deems recognition and emulation as the keystones of the impact that others as exemplars have on my process of self-shaping. She does not address a fundamental question: why does that specific exemplar (with her specific individuality) affect me (with my specific individuality)? The focus on recognition and emulation is so distorting that the issue of exemplariness is not at all interwoven with the issue of individuality.

All these five approaches are coordinates we could rest upon in order to account for the link between intersubjectivity and self-shaping. Nonetheless, we have brought to light the blind spots that prevent us from appealing to them. In order to account for this link, we will argue for a phenomenological perspective that mainly relies upon Husserl's stance on 
self-eidetic possibilities and Scheler's stance on exemplariness. We will argue that a phenomenological perspective allows us to argue for two key theses that are ruled out by the five approaches we have briefly taken into account: 1) other persons are eidetic variations of myself and this is why they might hold sway over my process of self-shaping [§3];2) exemplariness is the key to the link between intersubjectivity and self-shaping and this is how concretely other persons hold sway over my process of self-shaping: Scheler's stance on exemplariness makes us understand that it is not us who pick exemplars out; indeed, we are picked out by them and this thesis highlights the overarching contribution of Scheler to the debate revolving around exemplariness [\$4]. These goals put in the foreground the fruitfulness of broaching the issue at stake from a phenomenological perspective: a phenomenological analysis is able to meaningfully enrich our comprehension of the link between intersubjectivity and self-shaping. Nonetheless, what does it mean that we will tackle this issue from a phenomenological perspective? How could a phenomenological approach enrich our comprehension of this issue?

\section{Descriptive Phenomenology, its Key Points and its Theoretical, Applicative and Performative Commitment}

The answer to these questions lies in comprehending what characterizes phenomenology as a philosophical method of description and what makes the different scopes of its application possible, specifically, the topic of intersubjectivity and its link with self-shaping. Four key points seem to constitute the core of phenomenology regarded as a descriptive method of philosophical investigation: $i$ ) first-person perspective experience represents an unavoidable landmark for a phenomenological analysis because giving rise to phenomenological reflections means focusing on the double-sided nature of our experiences, simultaneously the subjective and intersubjective. On the one hand, one's experiences are marked by traits that solely proceed from the subject of the experience itself; on the other hand, one's experiences are marked by traits that also characterize other subjects' kindred experiences. This means that every single experience is neither solipsistic nor completely sharable. Phenomenological analyses come to grips with these two sides of the coin and, in so doing, clarify obfuscated features of the kind of experience at issue. ii) Identifying the essential traits of the phenomenon at stake (objectivity) and such traits should account for my own experience as well as for the experiences of others (intersubjectivity). iii) The effort of shedding light on the nature of the phenomena surrounding us in the world-oflife; that is to say, the effort of bringing to light the structure of the world-of-life and, in so doing, "phenomenalizing" what we talk about. iv) The task of justification (Rechtfertigung), i.e. the task of accounting for. The first and the second issue refer to two sides of the same coin: the former is related to the problem of givenness and the second to the problem of knowledge. The former poses the question as to "how, and under what conditions, objects with a determinate sense of being so-and-so are at all given to consciousness" (De Warren, 2009, p. 12). The latter poses the question as to "what is such-andsuch" (De Warren, 2009, p. 12). 
In the light of these four points that we deem as the keystones of phenomenology as a philosophical method of description, we argue that phenomenology is not confined to a method we could simply follow. Indeed, it seems it is a matter of a triple commitment, i.e. a theoretical, applicative, and performative commitment. What does this mean? When we apply phenomenology to phenomena that concern us (applicative commitment), we strive to comprehend their intrinsic essence (theoretical commitment). If we relate phenomenology (as a descriptive method of philosophical investigation) to the range of phenomena inhabiting Lebenswelt - to the scope of our own personal experiences - then we reach a high degree of clarification and comprehension regarding them and their essence. In so doing, we disclose ways of phenomenological reflection and application. We argue that phenomenology's nature consists in the disclosure of phenomenological ways of application. This means that it is possible for us to disclose new ways of phenomenological application - new ways of relating phenomenology to different kinds of experiences, scopes, phenomena, and so on. Applying phenomenology means relating it to "something"-for example, the topic of affectivity, emotions, intersubjectivity, self-shaping, and whatsoever-and combing through its essence. So, on the one hand, this applicative nature of phenomenology allows us to relate it to the link between intersubjectivity and self-shaping. On the other hand, the theoretical nature of phenomenology allows us to comprehend how this link plays out. In order for this disclosure of phenomenological ways of application to play out, a performative commitment is necessary: in order to carry out phenomenological reflections, we need to act, to do something. Phenomenology does not merely call for a theoretical and applicative commitment. It entails a strong performative commitment: we have to put the natural attitude into brackets, to carry out the phenomenological reduction, to vary the phenomena in their essential traits; or, according to the eidetic variation, to let the phenomenon catch our attention, and so on (cf. Husserl, 1976, §1-46).

This triple commitment flows into the possibility of giving rise to phenomenological analyses: nothing prevents us from grappling with every phenomenon from a phenomenological standpoint. Theoretical, applicative, and performative facets of phenomenology constitute the forces we rely on during the effort of bringing to light the essential traits of the phenomena surrounding us. For example, the applicative nature of phenomenology pointedly stands out in Scheler's thought since he relates phenomenology to different phenomena and, in so doing, discloses new phenomenological ways of reflection: phenomenology and individuality (Scheler, Der Formalismus in der Ethik und die materiale Wertethik), phenomenology and religion (Scheler, Vom Ewigen im Menschen), phenomenology and exemplars (Scheler, Vorbilder und Führer), and so on. Such an applicative phenomenological nature which spurs us to relate phenomenology to various phenomena so as to reach a higher degree of comprehension regarding them is unavoidably linked with a performative phenomenological nature: in order to undertake phenomenological reflections, to disclose new phenomenological ways, we are supposed to be active thinkers. 
Once phenomenology is chosen as a way of inquiry, the latter entails a double dynamic: if we appeal to phenomenology, we have to be aware of the double dynamic that such an appeal implies. On the one hand, phenomenology demands to be applied to that phenomenon or those phenomena which we wish to comprehend with regard to their intrinsic essence; thanks to this performative commitment we disclose ways of phenomenological reflection and application. On the other hand, we are supposed to examine better and in great detail the theoretical commitment that lays the foundation for such a disclosure.

Phenomenology inherently strives to be related to the scope of our own personal experiences. Such an application is not for its own sake, but rather for an overarching comprehension of our being in the world - the theoretical commitment of phenomenology. Otherwise, if phenomenology were conceived as a philosophical field that is supposed to be merely studied and not applied, then it would cease to be what its founder devised it to be and it would be forced to be less than it is actually capable of. Phenomenology is a philosophical method we should appeal to if we aim to gain evidence and clarification with regard to the phenomena surrounding us in the world-of-life. According to Husserl, phenomenological philosophy is not to be conceived as a mere life occupation in the ordinary sense ("ein bloß schönen Lebensberuf im gewöhnlichen Wortsinne"). Indeed, it appeals to and affects the innermost folds of life. For this reason, Husserl is proud of the kind of philosophy that Ingarden's stance exemplifies: he writes, I am sure about your future since you belong to that narrow group of my students who do not deem philosophy as a mere life occupation [Lebensberuf] in the ordinary sense; indeed, they think that philosophy is an occupation $[B e r u f]$ in the highest sense because it points to the unique vocation $[R u f]$ that pertains to the individual core of the person herself ${ }^{2}$ (cf. Ingarden, 1968, p. 34).

Phenomenological philosophy spurs us to turn to the world-of-life in order to comprehend the phenomena of the world-of-life-here we are concerned with the link between intersubjectivity and self-shaping. In so doing, phenomenological philosophy prevents us from merely interpreting the world-of-life in the light of philosophical explanations. Indeed, phenomenological philosophy spurs us to primarily turn to the world-of-life in order to find here what could guide us through the comprehension of the world-of-life itself. Phenomenology is a philosophical method we should appeal to if we want to gain evidence and clarification with regard to the phenomena surrounding us in the world-of-life. Such an application is not for its own sake: it strives for an overarching comprehension of our being in the world. The phenomenological way we tread in order to gain evidence and clarification is not a philosophical way that merely resembles, for example, the Socratic endeavour or any other philosophical attempt that purports to achieve the same goal. Phenomenological method has been here related to specific key points that clearly distinguish it in a sound manner. So, every philosopher who deals with phenomenology should be

\footnotetext{
${ }^{2}$ In Ingarden's own words: “ihrer Zukunft bin ich sicher. Sie gehören zu den ganz weniger meiner Schüler, denen die Philosophie nicht ein bloß schönen Lebensberuf im gewöhnlichen Wortsinne ist, sondern Beruf im höchsten Sinne, der auf einen über persönlichen, den Herzpunkt der Persönlichkeit treffenden Ruf hindeutet" (Ingarden, 1968, p. 34).
} 
willing to carry out the chief phenomenological task, that is, the effort of comprehending the essence of the phenomena inhabiting the world-of-life under the guidance of the phenomenological triple commitment and the four key points taken into account. These key points set the stage for a phenomenological analysis focused on the link between intersubjectivity and self-shaping. Therefore, we can apply phenomenology to this issue and develop a phenomenology of such a link. The fruitfulness of the nexus between phenomenology and this topic strictly stands out through the striking outcomes we can achieve by virtue of this nexus. In fact, tackling the link between intersubjectivity and self-shaping from a phenomenological viewpoint will enable us to argue for these key theses: 1) other persons are eidetic variations of myself and this is why they might hold sway over my process of self-shaping [§3]; 2) exemplariness is the key to the link between intersubjectivity and self-shaping and this is how other persons hold sway over my process of selfshaping; Max Scheler's stance on exemplariness will stress that it is not us who pick exemplars out —indeed, we are picked out by them [\$4].

\section{Eidetic Variation Related to the Self and Others as "Abwandlungen meiner Selbst"}

In a pithy text Husserl wonders whether it is possible to relate eidetic variation to the self: is "an eidetic variation of my self" feasible? How to let eidetic possibilities of my self blossom? ${ }^{4}$

At the beginning of this text, Husserl describes two main manners of self-knowledge. In the light of the first manner, I come to know myself starting from experiencing the world I inhabit. For example, when I perceive a tree, even if I am not reflecting upon myself, I somehow experience my perception, I somehow experience the way in which I perceive the tree I am now perceiving. In so doing, we achieve an indirect self-knowledge: we come to know some aspects of ourselves through our perceptions. We do not thematically focus on ourselves: we just focus on the experiences whereby we indirectly experience ourselves too. Husserl goes further than this and argues for the possibility of a direct self-knowledge. This process of direct self-knowledge is straightforwardly focused on myself: I thematically shift my attention to myself and try to gain self-knowledge in this way.

Husserl endeavours to better describe this direct way of self-knowledge and specifies that in order to really know myself, I need to know how I was in the past and how I will be in the future, that is to say, how I actually behaved in past circumstances and how I shall behave in possible circumstances. The first effort of self-knowledge requires me to reflect

\footnotetext{
3 "Eine eidetische Variation meiner selbst" (Husserl, 2012, p. 366).

${ }^{4}$ In Husserl's own words: “evidenter eidetischer Möglichkeiten meines konkreten Seins" (Husserl, 2012, p. 366). Phenomenologically, the expression "eidetic variation" refers to a method we can follow in order to identify the traits that constitute the essence of the phenomenon we are investigating. This method consists in mentally varying the phenomenon at issue in its essential traits (Husserl, 1976, §4, §70).
} 
upon my past life: in order to know myself as now I really am, I must know my entire past too and, especially, my manner of behaving or acting related to key circumstances. ${ }^{5}$ The second effort of self-knowledge requires that I explore the possibilities within me. Husserl maintains that this mode of self-exploration spurs me to appeal to some kind of imagination and wonder how I shall behave in possible future circumstances. So, I can also explore and investigate my factual possibilities related to myself. I can imagine myself in different and possible circumstances and wonder what I would do and how I would behave; naturally, in so doing, I can imagine circumstances that are remarkably far away from the concrete situation that now characterizes my present. ${ }^{6}$

So, the attempt to know oneself demands a double effort: on the one hand, I have to turn to the past and bring to light my actual and past individuality; on the other hand, I have to turn to the future and bring to light my possible and future individuality. While outlining this process, Husserl acknowledges that this dynamic of self-knowledge paradoxically relies upon a further process, which actually is the process of self-knowledge itself: this occurs because, in order to know how I would behave from a factual point of view, now I should strive to know my own self and, especially, its sense (Husserl specifies that the expression "I" is here related to the following specific meaning: what I am now, in the sense that I am this one and I am not another one). ${ }^{7}$ This apparent paradox ensues from the fact that if I want to know how I will behave in the future, I need to know the core and essence of my individuality as well as the impact that my past life had on it" (Husserl, 2012, pp. 367-368). ${ }^{8}$ So, how to pierce the spectrum of my possibilities?

Here Husserl is drawing our attention to an issue that is as pivotal as it is knotty: in order to know myself I have to imagine myself in possible circumstances, and in order to imagine myself in possible circumstances I have to know what I can and cannot vary about myself. Briefly, I need to know the essence of my individuality. How to grasp it? Husserl has just suggested that we should appeal to some kind of imagination through which we can imagine ourselves in different and possible circumstances. ${ }^{9}$ Now, what is Husserl referring to when using the term "imaginieren"?

\footnotetext{
${ }^{5}$ In Husserl's own words: “ $<$ um> mich kennenzulernen, wie ich jetzt wirklich bin, müsste ich also meine ganze Vergangenheit, mein vergangenes Mich-Verhalten unter den mir damals geltenden Situationen kennen" (Husserl, 2012, p. 366).

${ }^{6}$ In Husserl's own words: “ich kann danach auch meine faktischen Seinsmöglichkeiten erforschen. Ich kann mich in den verschiedensten möglichen Weltsituationen versetzt imaginieren und mich fragen, was ich da tun, wie da mein Verhalten sein würde. Natürlich kann ich da sehr weit abirren” (Husserl, 2012, p. 367).

${ }^{7}$ In Husserl's own words: "um zu wissen, wie ich mich da faktisch verhalten würde, ich jetzt, der ich jetzt der und kein anderer bin, müsste mein eigenes Sein in dem vollen, vorhin umzeichneten Sinn kennenlernen" (Husserl, 2012, p. 367).

8 "In mir liegt doch der ganze Niederschlag meines früheren Lebens" (Husserl, 2012, pp. 367-368): I embrace my entire past as well as its overarching effects upon my self.

${ }^{9}$ In Husserl's own words: "ich kann mich in den verschiedensten möglichen Weltsituationen versetzt imaginieren” (Husserl, 2012, p. 367): I can imagine myself in different and possible circumstances.
} 
At the suggestion of Husserl (Husserl, 2012, p. 368), let us wonder about ourselves and face such a far-reaching question: would I be willing to rob and then kill somebody? I have to examine and reflect upon the possibilities tethered to my own individuality and then I could say, "No, I could not do that. It would not be me." It seems I have to abide by strict limits while stretching the boundaries of my individuality: I imagine myself robbing and killing somebody and I realize that that person could not be me. There is something that prevents me from identifying myself with that kind of person. My process of selfshaping has to abide by constraints that hedge me in and seem to ensue from the core of my individuality.

How can I draw this conclusion so firmly? How can I understand which possibilities pertain to my individuality and which possibilities exceed the range of my possible self-formation? I have surely experienced that my individuality is liable to changes, so how can I be so sure that I could not find myself robbing and then killing somebody? Husserl appeals to specific terms to describe the kind of "mental exercise' that leads us to clearly comprehend how certain possibilities somehow concern, or do not concern, our own individuality. He mainly employs these key terms: hineindenken (literal meaning: to put oneself in somebody's position, to try to understand somebody's position), umphantasieren (literal meaning: to fantasize in the sense that I overturn what I fantasize about), festhalten (literal meaning: to hold tightly), überschreiten (literal meaning: to go beyond), mich umdenken (literal meaning: to change one's opinion, to rethink), gebunden (constrained), frei variieren (to vary freely) and frei phantasieren (to fantasize freely). These terms refer to acts that enable me to know myself in order to shape myself accordingly: I investigate the possibilities of my individuality by turning upside down the certainties about myself. I "overturn" myself and, in so doing, I start becoming present to myself. Umphantasieren, überschreiten, mich umdenken refer to this act of "self-overturning" (especially by virtue of the German prefix -um, which inherently provides the word with a nuance related to this idea of "overturning"). Frei variieren and frei phantasieren refer to the ability we appeal to when overturning ourselves: we appeal to an act of free phantasy, that is, by freely fantasizing we manage to grasp the facets of our individuality that act as constraints on stretching the boundaries of our individuality. ${ }^{10}$ Festhalten and gebunden refer to the constraints we come across while carrying

\footnotetext{
${ }^{10}$ In Phänomenologie und Erkenntnistheorie Husserl draws a sharp distinction between two different kinds of phantasy: freie Phantasie and träumende Phantasie. According to Husserl, I rely on freie Phantasie when I appeal to eidetic variation, whereas I rely on träumende Phantasie (reine Phantasie) when I daydream about something (cf. Husserl, 1980, §1-19). The appeal to freie Phantasie implies that "ich stelle mich [...] auf den Boden der Phantasie" (Husserl, 2015, p. 184): the sphere of reality and the sphere of phantasy definitively overlap. On the contrary, the appeal to träumende Phantasie makes me quasi-experience the fantasized events, I quasi-judge them and I take a position on them through pleasure or displeasure. So, the kind of phantasy we often refer to is, in Husserl's terms, träumende Phantasie. Freie Phantasie makes eidetic variation possible: if we appeal to eidetic variation, we are not lost in distant phantasy scenarios; indeed, we are tremendously absorbed in the world we inhabit, and we try to grasp the essence of what concerns us by varying it. For example, in his research, a geometer appeals to freie Phantasie: "in phantasy, to be sure, he must make an effort to attain clear intuitions from which he is exempted by the sketch or model. But in actually sketching and constructing a model he is restricted; in phantasy he has incomparably more freedom reshaping at will the figures feigned" (Husserl, 1983, p. 159). So,
} 
out this exercise of free variation: while fantasizing about ourselves we find ourselves abiding by certain constraints that prevent us from fantasizing everything about ourselves. When we detect such constraints, we are spotting the boundaries that deeply define our personality and the possibilities of our process of self-shaping.

This entails that these acts, as a whole, set the stage for a process of self-presence. Fantasizing about myself allows me to pinpoint the borders beyond which I cannot go without turning into another type of individual. Fantasizing about myself allows me to gradually become present to myself since I pinpoint the range of possibilities that pertain to my individuality. This exercise of phantasy leads me to clearly assert claims like "I want that," "I cannot do this," "I am not that one," "It would not be me": all these expressions reveal different facets of my individuality so that I gradually become present to myself. I vary myself in aspects that I regard as hallmarks of my individuality, I strive to narrow and stretch the boundaries of my individuality in the hope that I manage to go beyond them by focusing on the possibilities of myself I can devise by freely fantasizing. I strive to turn myself upside down by trying to be as attentive as possible to the way my individuality alters and adjusts to the circumstances I devise by freely fantasizing. However insightful this free fantasizing could be, it bumps against an obstacle: when I vary myself in my bedrocks, what do I have to keep fixed [festhalten]? When I say that the person who robs and then kills someone is not me, what am I relying upon to claim so? What enables me to keep on recognizing myself within the wide spectrum of self-possibilities I devise by freely fantasizing?

According to Husserl, fantasizing about my self implies two different dimensions: on the one hand, something has to remain fixed (me myself and my character); on the other hand, something has to alter (my factual self). This double process entails that my self-possibilities are inherently related to my factual self; that is to say, they are somehow constrained by it. ${ }^{11}$ While I vary myself, there is something that I cannot vary: this " $x$ " enables me to stretch the boundaries of my individuality and then say that I am not that person who robs and then kills somebody. In so doing, I get over these obstacles of my factual individuality and grasp the possibilities that I can conceive by appeal to phantasy. ${ }^{12}$ While I vary myself, I realize that there are a few constraints by which I am hedged in. I come to realize that I cannot imagine everything about myself; that is, when I imagine myself killing a person, I come to realize that I am not that kind of person. Husserl refers to this "x," on which I unavoidably lean while varying myself, as the "eidetic I." So, Husserl argues that if I relate

when Husserl talks about Phantasie in relation to eidetic variation, he is referring to freie Phantasie. Unfortunately, this issue lies outside the frame of this research: see also Husserl (1976, p. 311; 1983, pp. 159-160; 2015, p. 184).

\footnotetext{
${ }^{11}$ In Husserl's own words: "mich also umphantasieren, das ergibt, wenn ich mich als identisches Ich der Akte und als das Ich in der Identität meines 'Charakters' festhalte, zwar die Faktizität überschreitende Möglichkeiten, andererseits aber doch nur Möglichkeiten meines faktischen Ich, wie ich jetzt bin, an mich 'individuell' (im personalen Sinn) gebunden" (Husserl, 2012, p. 368).

12 "Überschreite ich nun auch diese Schranke meiner personalen Individualität, so erhalte ich völlig freie Phantasiemöglichkeiten, die für mich in keinem Sinn 'reale' Möglichkeiten sind” (Husserl, 2012, p. 368).
} 
eidetic variation to myself, then I gain an "eidetic I." If I delve into the spectrum of possibilities I conceive by appeal to phantasy, I can investigate and alter them: such possibilities contradict myself as I am now, and this is why if I investigate them, I come to grasp my essence, that is, the "Eidos Ich." 13

Thanks to free phantasy I grasp possibilities that even withhold the evidence of my individuality. I devise variations that clearly clash with my individuality. Within this spectrum of variations, Husserl specifies how others play a pivotal role. This occurs since other persons are to be regarded as variations of myself: this entails that they could bring to light eidetic possibilities related to myself; according to Husserl, the other person is an intentional variation of myself and every variation is the key to my eidetic possibilities. ${ }^{14} \mathrm{We}$ can interpret Husserl's words and claim that since others are persons like and-as individuals - unlike me, then they exemplify eidetic possibilities that could also pertain to myself. ${ }^{15}$ It follows that in the process of self-eidetic variation, others turn out to play a pivotal role: they shed light on one's own eidetic possibilities, on untaken possibilities that deeply relate to one's own individual essence. In order to fully comprehend the role of others in this process, it is necessary to better account for the essence of eidetic variation itself.

My ability to vary myself is strictly restricted since I cannot get over insuperable handles. How to account for these constraints? On the one hand, they circumscribe the possibilities of what I can vary and so they essentially contribute to the process of self-shaping; however, they hedge me in since they restrict the spectrum of my possibilities. While varying myself in order to better know my possibilities, I come across limits that seem to restrict my activity of fantasizing. How to treat these unavoidable limits that somehow hedge us in? How is it possible that while free fantasizing we go beyond factuality and, at the same time, find ourselves hedged in by it? These sorts of constraints that underlie eidetic variation lead us to grasp the essence of what we are varying, but how to account for them? Eidetic variation does not rely upon "an empirical comparison" solely. It is a kind of empirical comparison that aims to detect the universal essences that come to prominence "in the empirically given." Husserl highlights that these universal essences have to be freed from contingency. He provides an insightful description of this process:

let us attempt to get a first concept of this operation. It is based on the modification [Abwandlung] of an experienced or imagined objectivity, turning it into an arbitrary example, which,

\footnotetext{
${ }^{13}$ In Husserl's own words, "und nur wenn ich sie [Phantasiemöglichkeiten], die mit meinem Sein, wie ich als dieser bin, in Wiederspruch stehen, in der Einstellung der Beliebigkeit heranziehe, ansetze und wandle, kann ich eine Wesensallgemeinheit gewinnen, in welcher ich, das faktische Ich, zu einem Ich im Universum meiner freien fiktiven Möglichkeiten, meiner eidetischen, werde. So gewinne ich [...] ein allgemeines Wesen, $<$ das $>$ Eidos Ich" (Husserl, 2012, p. 368).

${ }^{14}$ In Husserl's own words: “der Andere [ist] eine intentionale Abwandlung meiner selbst [...] und < zwar $>$ offenbar so, dass jede solche Abwandlung [...] eine meiner eidetischen (aber nicht schon eine meiner faktischen) Möglichkeiten für mich zur Geltung und eventuell zu einer gewissen Evidenz bringt” (Husserl, 2012, p. 368).

${ }^{15}$ Cf. Husserl (2012, p. 369): “was er [der Andere] tut, verstehe ich ihn selbst als Person, ihn, wie er 'Individuum' ist, noch lange nicht." Husserl is claiming that, in the light of her deeds, the other person appears to me as a person and this means that I regard her as a person, but the other person as an individual remains beyond my grasp.
} 
at the same time, receives the character of a guiding "model," a point of departure for the production of an infinitely open multiplicity of variants [den Charakter des leitenden "Vorbildes" erhält, des Ausgangsgliedes für die Erzeugung einer offen endlosen Mannigfaltigkeit von Varianten]. It is based, therefore, on a variation. In other words, for its modification in pure imagination, we let ourselves be guided by the fact taken as a model [wir lassen uns vom Faktum als Vorbild für seine Umgestaltung in reiner Phantasie leiten]. (Husserl, 1973, p. 340)

There is a midpoint between the act of varying and the act of grasping the essence: there is a Vorbild, which guides us through "the production of an infinitely open multiplicity of variants." While varying a "thing" in order to grasp its essence, we are free to fantasize about its variations: the more we vary, the more we identify the Vorbilder that help us to understand what we can vary and what we cannot vary about the thing itself. If we abide by these constraints, which we ourselves detect by varying, we come to grasp the essence we were searching for. We shift from an experienced or imagined objectivity to a Vorbild that guides us through the spectrum of variants and, in so doing, we gradually become aware of a unity that "runs through this multiplicity":

it then becomes evident that a unity [Einheit] runs through this multiplicity of successive figures, that in such free variations of an original image, e.g., of a thing, an invariant [Invariante] is necessarily retained as the necessary general form, without which an object such as this thing, as an example of its kind, would not be thinkable at all. While what differentiates the variants remains indifferent to us, this form stands out in the practice of voluntary variation, and as an absolutely identical content, an invariable what, according to which all the variants coincide: a general essence [ein allgemeines Wesen]. (Husserl, 1973, p. 340)

So, the balance between freedom and constraints is based on Vorbilder, which account for the constraints we come across while carrying out eidetic variation. Far from merely restricting our freedom, these constraints guide us through the identification of essences. The identity (of the object of my act of fantasizing) acts as a constraint on my fantasizing. While I am fantasizing about centaurs and while I am eidetically varying a sound, I am hedged in by the identity of centaurs as well as the identity of the sound. Just as I would not keep on fantasizing about a centaur anymore if I did not abide by the constraints defining centaur's identity, so I would not keep on varying the essence of a sound anymore if I did not abide by the constraints defining the sound's identity. Far from merely restricting our ability to fantasize, this gebundene Freiheit nourishes frei Phantasie and reine Phantasie. What matters here is the link between this gebundene Freiheit and the kind of phantasy implied by eidetic variation, that is, free phantasy. Husserl argues very clearly that in free phantasy we are not completely free since the identity of what we are varying is an obstacle we cannot dodge. Far from restricting our freedom, this constraint is the basis on which eidetic variation could play out (cf. Husserl, 1983, p. 357).

In fantasizing we can freely give shape, while in normal experiencing we are somehow less free and more restricted. In spite of this freedom, what we fantasize about keeps its identity fixed [festhalten]. Free phantasy yields possibilities that are at the same time free and restricted: while fantasizing, we ourselves are at the same time free and restricted. Such a restriction is due the identity of what we fantasize about: as much as we are free, 
we cannot withhold the identity of what we are fantasizing about. On the one hand, eidetic variation requires us to question the identity of the "thing" we are varying, but on the other hand the identity of the "thing" itself acts as an insuperable limit (cf. Husserl, 1973, pp. 342-343). While trying to grasp the essence of the sound, I can fantasize about a sound without a timbre and this means that I am somehow modifying its identity. But at the same time, I draw the conclusion that a sound without a timbre is not a sound and this means that I am referring to the identity of the sound as the pivotal parameter that enables me to discern whether I am thinking about a sound or not. "Die Phantasie ergibt Möglichkeiten" (Husserl, 2015, p. 182): by appeal to phantasy I can yield possibilities that are free and restricted at the same time.

Husserl describes others as variations of myself - argues that others could bring to light eidetic possibilities related to my own individuality and employs the term Vorbilder to describe the mid "models" that guide us through eidetic variation. It follows that other persons could crucially hold sway over my process of self-shaping since they - as variations of myself - could bring to light eidetic possibilities related to my individuality. Through this paragraph we argued that by appeal to Husserl's stance on eidetic variation related to the self, we come to understand why other persons might hold sway over one's process of self-shaping. Our appeal to Husserl is a fundamental keystone of our phenomenological analysis of the link between intersubjectivity and self-shaping and in the next paragraph we will relate it to Scheler's stance on exemplariness, which we will regard as the key to the link between intersubjectivity and self-shaping: we are arguing for a phenomenological theory that relies on both Husserl and Scheler to account for this link.

\section{Exemplariness as the Key to the Link between Intersubjectivity and Self-Shaping: Exemplars and the Ought-To-Be They Exemplify}

Starting from Husserl, we can claim that, in order to know and shape myself, other persons play a fundamental role since they bring to light eidetic variations of myself and these variations help me to grasp different facets of my individuality. Furthermore, in order to let myself be affected by others I have to be willing to conceive myself differently from the type of individual I think I am: free phantasy is the ability that enables me to stretch the horizon of my eidetic possibilities. If we now relate these theses to Scheler's stance on exemplariness, we come to realize that exemplariness is the keystone that makes the process of self-shaping dependent on others. We are arguing that Husserl made us understand why other persons might hold sway over my process of self-shaping (they are eidetic variations of myself) and Scheler will make us understand how this impact plays out (other persons hold sway over me as exemplars): starting from Husserl and Scheler, we will go beyond them, arguing that others as exemplars represent untaken possibilities of myself.

The strong thesis we will develop starting from Scheler is that we cannot presume to know and shape ourselves without other persons playing a fundamental role in such a process. Sure, other persons could hold sway over my process of self-shaping in very different 
manners, as the novel by Tolstoy showed at the beginning. However, the specific kind of influence we are going to discuss is exemplariness: others do not simply influence me, do not simply make me imitate them, do not simply make me grasp new facets of myself. They are exemplars for me. Exemplariness only is the key to the link between intersubjectivity and self-shaping since it is the deepest kind ${ }^{16}$ of impact that other persons could have on the process of self-shaping. We intend to argue that the link between intersubjectivity and self-shaping occurs in the light of exemplariness: others might hold sway over my self-shaping insofar as they can become exemplars for me. If we lean on Scheler's standpoint, we are able to pose and answer questions that traditional approaches - the five we examined in the first paragraph — do not even consider. When we consider philosophical stances upon exemplariness, we are faced with theories that mainly spur us to pose such questions: Which exemplars should we choose? How to recognize them? How to imitate them? Zagzebski (2017), for instance, regards admiration as the key to recognition: if I admire a person, then this is a good reason for me to recognize the inherent exemplarity of that person. So, I choose to imitate the persons that I have recognized as exemplars since they are admirable. According to Scheler, if we merely focus on recognition, choice, and imitation, then we are confined to examine what he refers to as "models." "Exemplars" are far more important than models since they nourish one's own individuality: they constitute a fundamental keystone of the whole process of self-shaping. On the contrary, models affect my actions only. Models' way of influencing apparently resembles exemplars' way of influencing: the former holds sway solely over the sphere of acting, while the latter holds sway over the sphere of being and then acting.

Scheler propels us to turn the problem upside down: How are we affected by exemplars? How do they affect my individuality? Far from being a matter of recognition, choice, and imitation, Scheler urges us to consider the process of influence that is typical of exemplars as a pre-logical and unaware process that affects me and not you since my individuality is such that it is affected by the individuality of that specific exemplar. Scheler makes us treat the question of exemplariness from the standpoint of the process of the formation of individuality - the process of self-shaping: exemplars hold sway over such a process. It is not simply a matter of emulation of actions. Indeed, it is a matter of a radical influence over the sphere of individuality. Accounts like Zagzebski's fail to recognize the link that inherently ties exemplariness to individuality: why does that specific exemplar affect $m e$ ? Thanks to Schelerian theses we are able to understand how exemplariness can be comprehended only in the light of its double link with individuality: it crucially holds sway over individuality and the reason why a certain person is affected by certain exemplars depends upon the specific individuality of the person and exemplars. So, the hallmark of Scheler's stance on exemplariness is its dynamic of influence: it is not me who picks out exemplars, but I find myself picked out by them by virtue of my specific individuality and the specific individuality of the exemplars at stake. Starting from this thesis we will go beyond Scheler and-in

\footnotetext{
${ }^{16}$ This thesis does not prevent us from arguing that other modes of influencing one's process of self-shaping and self-knowledge are possible. The point is that exemplariness culminates in the impact that one might have over one's process of self-shaping and self-knowledge (Scheler, 1973, p. 574). Exemplariness is the deepest possible impact.
} 
the light of Husserl's remarks - argue that exemplars who affect me exemplify untaken possibilities of myself. If others could potentially exemplify eidetic possibilities of myself, then they become exemplars for me on condition that the eidetic possibilities that they might exemplify have an impact on my own process of self-shaping by making me aware of something crucial regarding my individuality. Such a claim is the outcome of an analysis based on both Husserl's and Scheler's theses: Husserl spurs us to argue that other persons make me grasp the eidetic possibilities of myself since they are variations of myself; Scheler spurs us to argue that other persons play a pivotal role in my process of self-shaping since they might become exemplars for me - they could make me understand overshadowed facets of my individuality. Scheler makes us understand that the sphere of influence typical of exemplariness is the dimension of being rather than the dimension of acting: exemplars affect not how I act, but the type of individual I think I am and want to be.

What are exemplars [Vorbilder] for Scheler? The first step in facing this question requires us to focus on the German term Vorbild, as Scheler employs it. As Cusinato (2011) clearly remarks, Scheler ascribes to this term a double meaning: according to its central and most important meaning, it refers to a strength that transforms the individuality of the person who is affected; according to its superficial and more common meaning, it refers to a strength that works through imitation. At the suggestion of Cusinato, the first meaning is translated into the word "exemplar," and the second into the word "model."

Which features characterize exemplars? Scheler (1973, pp. 572-575, 583-584) draws a sharp distinction between norms ("Normen") and exemplars ("Vorbilder"). Following Scheler, what exemplars give rise to is an ideal ought rather than a norm. Norms - and, subsequently, leadership — pertain to universally valid and universal propositions of oughtness and such propositions have a valuable action as content. On the contrary, exemplars do not pertain to the sphere of mere actions. They refer to the dimension of To-Be. Leadership is a matter of doing something, while exemplariness is a way of being. This ought-tobe is experienced as "it obliges me to follow" ("es verpflichtet mich zu folgen") rather than as "I am obliged to follow" ("ich bin verpflichtet zu folgen"). Far from being a "suggestive Kraft," it is a sort of powerful tug ("machtvoller Zug") that stems from the exemplar. Exemplars draw persons ("zu sich hinan-ziehen") towards them. We are affected by them without choosing to follow them. We do not actively move towards them. Exemplars are goal-determining ("ziel-bestimmend"), they are not a goal in itself after which we strive or an end that we could even posit. Within this framework, Scheler argues that fidelity ("Gefolgschaft") is the link that ties a person to the individuality of the exemplar. This relation cannot be reduced to a mere imitation ("Nachahmung") or an effort of copying ("Kopieren") the exemplar. My individuality is not erased in the light of the exemplar's individuality. Fidelity is the only relation by which the morally positive personal values of person $A$ can immediately bring about the birth of the same personal values for person $B$. With regard to the uniqueness typical of the impact of exemplariness, Scheler claims:

nothing on earth allows a person to become good so originally and immediately and necessarily as the evidential and adequate intuition [Anschauung] of a good person in his goodness. 
This relation is absolutely superior to any other relation in terms of a possible becoming good of which it can be considered the origin. It is superior to $B$ 's obeying the orders and commands of $A$, because this obedience can never follow from an autonomous and immediate insight into the value of what is commanded, and because this obedience can aim only at action, not at the moral tenor and not at all at the being of the person. (Scheler, 1973, p. 574)

Subsequently, the relation of exemplariness strictly preserves the autonomous will of the person who achieves fidelity. This happens since the transformation at stake concerns the being of the person rather than her willing and acting. As Scheler specifies, "the highest effectiveness of the good person on the moral cosmos lies in the pure value of exemplariness [Vorbildwert]" (Scheler, 1973, p. 575). Exemplariness is the primary vehicle for all changes that persons could give rise to and this effectiveness is more radical than the kind of effectiveness typical of norms because it is the person herself that gives rise to a process of transformation (“die Bewegung der Umbildung," Scheler, 2013, p. 1102) of another person. The morally relevant transformation that stems from exemplariness is fidelity itself ("Folge," "Nachfolge," "Gefolgschaft"). Such a transformation is a "growth of the being of the person" and it occurs by "following" the exemplar a certain person exemplifies:

this "following" is not to be understood in the sense of willing and acting, which aim only at obedience to true commands or pedagogical pseudo commands, or at copying. Willing and acting can consist in this and can be partially heteronomous. "Following," however, is to be understood in the sense of free devotion [Hingabe] to the content of personal value that is accessible to autonomous insight. (Scheler, 1973, p. 580)

In so doing, we become like the exemplar as a person, we do not become what the exemplar is: this entails learning to will and act as the exemplar wills and acts. We do not will what the exemplar wills and we do not act the same way in which the exemplar acts. So, the growing adaption ("Hineinbildung") of the person to the exemplar has a crushing impact on the process of self-shaping ("Neubildung") and such an impact brings about a radical personal transformation ("Umbildung"). Scheler stresses how the acts that underlie exemplariness are not grounded in acts of willing or imitating. Therefore, judgement and choice do not play any pivotal role here:

our consciousness of an [exemplar] is entirely prelogical and prior to the comprehension of even possible spheres of choice. It would be most naïve to assume that one must judge whether something is or is not an [exemplar] in order for it to become an [exemplar], or that one must judge and state what and who are supposed to be [exemplars] before they can be [exemplars]. (Scheler, 1973, p. 578)

Under the guidance of these Schelerian remarks, we have reasons to argue that exemplars pierce the deepest and allegedly inaccessible core of our own individuality and could give rise to profound changes in our awareness of this core. However, in order to let us be moved and affected by exemplars, we have to dare to call into question the type of individual we think we are. The sway of exemplars makes room for questions and doubts we have to face at our own risk. 
So, if we lean on Scheler's stance, we could surmise that exemplars primarily require a specific way of being and then acting and willing, while norms and leaders require a specific way of acting: exemplars - rather than norms and corresponding leaders - play a crucial and pivotal role in the whole process of self-shaping, whereas leadership and corresponding norms show their effectiveness in social and public life. The effectiveness of exemplars is more obscure insofar as they strive to shape the deepest layers of individuality. Norms demand a specific way of acting, whereas exemplars primarily require a specific way of being and then acting and willing. Distinguishing exemplars and leaders seems to be quite easy since leadership is distinctly grounded in commands and obedience. Unfortunately, it is fairly easy to mistake exemplars for models, but Scheler distinguishes them in a radical way. Models' way of influencing superficially resembles exemplars' way of influencing: the former holds sway solely over the sphere of acting, while the latter holds sway over the sphere of being and then acting.

Scheler argues that models seduce, while exemplars lead the way. At the suggestion of Cusinato (2014), the Latin verb that better explains models' sway is seduco, while the Latin verb that better explains exemplars' sway is conduco. The former refers to a movement towards the person who is drawn and lured by the model itself; the latter refers to a movement that takes place by virtue of the cooperation between the person and the exemplar. In fact, the exemplar leads the person beyond herself: they walk together so as to overcome the self of the person. This means that we need to "empty ourselves out" in order to let the exemplars have a bearing on us. It is a twofold movement: on the one hand, the exemplar has a huge amount of influence over me and I let myself be shaped by her; on the other hand, it is my individuality that guides me through this process of personal transformation. This does not entail that exemplars brush my individuality aside; indeed, they bolster my confidence in the type of individual who I am - they let my individuality out and nourish it. I could be deluded into knowing who I am, and an exemplar is able to shake my confidence to its foundations. It is worth noticing that we do not find ourselves under duress when exemplars bear upon us: it fully depends upon us whether to follow or not to follow the exemplar that has affected us. Surely, the beginning of this path does not depend upon us: at the beginning we experience just a powerful tug whose influence we cannot master; however, such a path keeps on playing out only on condition that we cooperate with the exemplar in shaping ourselves.

Exemplars call for a strong individuality, whereas models call for imitation. In order to let us be moved and affected by exemplars, we have to dare to call into question the type of individual we think we are. Exemplars spur us to give ourselves a new form: they do not dictate anything to us. Surely, it is simpler to follow a model. It is a very comfortable shortcut: I am deceiving myself by thinking that I have grasped the core of myself. Unfortunately, I am just camouflaging myself by copying the model in the way she is. My individuality vanishes since I yearn to become what another person is; I do not exist anymore since I merely copy the existence of the model. This starting act of copying quickly lapses into further acts of copying. I end up being dragged by a growing urge and, ultimately, I do not desire anymore since I merely try to copy the desires of the model: I do not decide 
anymore since I merely try to copy the decisions of the model. This "slippery slope" transforms my existence into someone else's existence, my desires into someone else's desires, my decisions into someone else's decisions and so on and so forth. This whole movement unavoidably gives rise to envy and resentment: I am not like the person I yearn so much to be. Such an urge completely clouds my own individuality.

In the light of Schelerian remarks and Cusinato's notable insights, we could devise a clear and sound portrait of exemplars and models. Exemplars guide us beyond ourselves in order for us to understand what we care about the most. On the contrary, models do not make us get away from ourselves: I do not have to come to the fore since I am completely overshadowed by the individuality of the model. We have to resist the temptation to follow models instead of exemplars. It is tempting to let ourselves be moved by models: we do not run any risk if we try to be someone other than us. The force typical of exemplars consists in their way of looking at us: they are able to grasp something that inherently pertains to us but still it does not concretely take place in us. They just provide me with a starting inkling that something that strongly pertains to my own individuality does not actually take place in my life. Surely, I can quash such an inkling and not set the stage for a rearrangement of myself - for a process of self-shaping and self-knowledge. Models even out our individuality, while exemplars pick us out among others. Models crush our own hallmarks and differences, while exemplars are able to recognize them and make us stand out. Models force us to fix our eyes on them and we become blind to ourselves: they make us walk away from the opportunity of going beyond ourselves in order to become present to us. Models make persons equal, while exemplars make persons different. Exemplars let differences emerge in order for persons to undertake the path that makes them individuals. Models force us to copy and imitate, while exemplars give us the chance to cast doubt on ourselves in order for us to grasp the core of our own individuality. Exemplars make us derail in order for us to find ourselves, while models make us walk down railway tracks and we end up being someone other than us. Exemplariness is the primary vehicle for all changes: Scheler describes the principle of exemplariness ("das Vorbildprinzip") as the primary vehicle for all changes in the ethical dimension ("das primäre Vehikel aller Veränderungen in der sittlichen Welt," Scheler, 2013, p. 1102).

From a Schelerian perspective, exemplars' strength is not based on obedience (like leadership) or copying (like models); indeed, exemplars' strength embodies a space where I can maieutically shape and re-shape myself. Such an opportunity I am given is concretely embodied: the exemplar makes herself the concrete personal presence of the opportunity to reorchestrate myself. I experience the other person as a Vor-bildung: I am faced withI am before - the concrete existence of a real person whose individuality strikes me since it exemplifies "something" that deeply relates to my own individuality too, but still does not take place in my life.

Before we conclude, it is worth improving our account of exemplars by a reference to the degree of awareness that Scheler ascribes to the dynamic of influence typical of exemplariness. In Vorbilder und Führer, Scheler draws an insightful distinction between deeply 
effective exemplars and exemplars we reflect upon. Scheler argues that deeply effective exemplars work in a similar way as "artistic laws." Artists do not point voluntarily at these laws, but they apply them. On the contrary, the more artists drift away from them, the more they become aware of them and their corresponding effectiveness. For Scheler, exemplars work in the same way in which "artistic laws" work. This means that we are not fully aware of what is occurring: we are aware of a change that is taking place in us, but we cannot consciously master the way in which it plays out. In the wake of this remark, Cusinato (2014) argues that the more exemplariness plays out unconsciously, the more it holds sway on the process of self-shaping of a given person. Cusinato maintains that it is not a matter of a subjective purpose - something that sounds like "I want to follow that exemplar." Indeed, it is primarily a matter of a concrete proof: actions speak louder than words and I am now before a person-a Vor-bilder (cf. Cusinato, 2007, p. 54) -who grasps my untaken possibilities and understands something about my individuality that I have never understood before. Hence, according to Scheler, awareness does not play any pivotal role, at least at first: if we aim to be affected by exemplars, we will not be, and the influence itself does not play out if we aim to master it. As Scheler claims, exemplars' influence is a powerful tug rather than a dynamic we can author. Nonetheless, as Scheler claims, awareness could come into play at a later stage. This means that, even though I cannot oversee the process of influence, I can reflect upon what is happening to me.

But what about the awareness typical of exemplars? To what extent are exemplars aware of their influence? Do they have to be aware? Previous reflections allow us to argue that leaders have to know to be leaders, but models can be unaware of their influence; exemplars do not have to know to be exemplars (at least at the beginning) and do not have to want to be such. What does this mean? If I am a leader, then I want others to follow my orders and so I have to be aware of the impact I am having on them. If I am a model, my hypothetical influence is not based on commands and orders: it is based on imitation and inherently regards the dimension of actions. Someone could imitate my actions and I might be absolutely unaware that such an imitation is taking place. If I am an exemplar, it is possible that I am unaware of the impact I am having on someone's process of self-shaping: what matters is that exemplars are not this on purpose. The two remarkable differences between models and exemplars concern the sphere of influence and the sphere of choice: the influence of models pertains to actions; the influence of exemplars pertains to the sphere of being; models can choose to be models, exemplars cannot choose to be exemplars. The fact that exemplars cannot choose to be exemplars follows from the innermost nature of exemplariness, which depends upon concrete proofs rather than subjective plans or intentions. I become an exemplar if my individuality makes someone else aware of untaken possibilities of her individuality. Contrary to exemplariness, I am free to decide to become a model for someone: if you aim to achieve goal "x," I can suggest that you imitate my actions since I have already achieved goal "x." Similarly, it could happen that - without me being aware that such an imitation is actually taking place-someone imitates my actions since I succeeded in achieving goal "x." Contrary to models, exemplars do not give rise to something identical: far from urging me to imitate them, exemplars 
give rise to something new since they inspire me to reshape myself in the light of the new self-awareness I gain thanks to their impact on my self-knowledge.

Exemplars aid me in understanding the type of individual I am and who I shall become, make me question my degree of self-knowledge, make me wonder whether my life is consistent with my individuality, specifically, with untaken possibilities related to my individuality that exemplars bring to light.

\section{Concluding Remarks}

Other persons as exemplars represent a space where we are given the opportunity to reorchestrate ourselves: others as exemplars help me grasp untaken possibilities of my individuality and then it is me who decides whether to reorchestrate myself accordingly, or not. This means that, in order to let me be possibly affected by exemplars, I must be willing and ready to reorchestrate myself. I must be ready to discover new facets of myself, I must be ready to think about myself differently than I did before and do now. In so doing, I let myself be possibly affected by exemplars, which are the sources of the deepest personal upheavals. If I were not willing to conceive myself differently, I would never be affected by exemplars since they radically question what I think about my individuality. The account of exemplariness that we provided implies a point that we should highlight: we cannot presume to know and shape ourselves without other persons playing a fundamental role in such processes. Exemplars make me grasp untaken possibilities of my individuality and, if I am willing to conceive myself differently, then I give myself the opportunity to embrace these possibilities in my process of self-knowledge and reorchestrate myself in the light of them. These possibilities inherently regard my individuality, but they inherently remain beyond my grasp if I am not willing to question myself in the light of others' influence.

"The other person is an intentional variation of my self" ("der Andere [ist] eine intentionale Abwandlung meiner selbst," Husserl, 2012, p. 368) and so other persons could crushingly shed light on my self-eidetic possibilities: we relied on Husserl's thesis to argue that this deep impact that other persons have over me plays out as exemplariness. We argued for this phenomenological reference from Husserl to Scheler so as to understand the nexus occurring between intersubjectivity and self-shaping: since other persons embody untaken possibilities of myself, then they could become exemplars for me and affect my life and deeply hold sway over my process of self-shaping. Exemplars do not simply affect my actions or my beliefs. Exemplars are not mere models or leaders. Exemplars deeply affect my self-awareness: they make me grasp overshadowed facets of my own individuality. This influence depends upon the fact that others are able to shed light on eidetic possibilities related to my own individuality since they embody untaken possibilities of myself. Husserl's thesis (“der Andere [ist] eine intentionale Abwandlung meiner selbst") and Scheler's thesis (others could become exemplars for me) enabled us to argue for a thesis that relies upon these two issues and, at the same time, go beyond them through the notion of "untaken possibilities": others as exemplars shed light on eidetic possibilities related to 
myself and others could become exemplars for me since they are variations of myself; that is, they exemplify untaken possibilities of myself. Others as exemplars have a crushing impact on my process of self-shaping because they make me discover untaken possibilities of myself: exemplariness is the key to the link between the issue of intersubjectivity and the process of self-shaping.

Exemplars urge us to look at them as exemplars; that is, they urge us to go beyond their inherent individuality so as to grasp our own individuality in the light of their exemplarity. Other persons as exemplars comprehend something that pertains to my individuality, although it does not take place yet: this "something" is a possibility related to my individuality, but it is still untaken. There are some eidetic possibilities that stem from our individuality that are still untaken: exemplars turn our certainties upside down so as to make us realize such possibilities and, possibly, spur us to reorchestrate ourselves accordingly.

\section{Refereces}

Babbit, I. (1908). Literature and the American College: Essays in Defense of the Humanities. Cambridge, UK: The Riverside Press.

Cusinato, G. (2011). Sull'esemplarità aurorale. In M. Scheler, Modelli e capi: Per un personalismo etico in sociologia e filosofia della storia (pp. 7-28). Milan, Italy: Franco Angeli.

Cusinato, G. (2014). Periagoge: Teoria della singolarità e filosofia come cura del desiderio. Verona, Italy: QuiEdit.

De Warren, N. (2009). Husserl and the Promise of Time: Subjectivity in Transcendental Phenomenology. Cambridge, UK: Cambridge University Press.

Fennell, J. M. (2016). What Is the Moral Imagination? Retrieved 2018, 20 September from

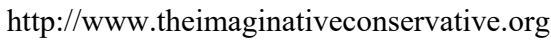

Husserl, E. (1973). Experience and Judgement. (J. S. Churchill \& K. Ameriks, Trans.). Evanston, IL: Northwestern University Press. (Original work published 1939)

Husserl, E. (1976). Ideen zu Einer Reinen Phänomenologie und Phänomenologischen Philosophie: Erstes Buch: Allgemeine Einführung in die Reine Phänomenologie. The Hague, the Netherlands: Martinus Nijhoff. (Original work published 1913)

Husserl, E. (1980). Phantasie, Bildbewusstsein, Erinnerung. Zur Phänomenologie der Anschaulichen Vergegenwärtigungen Texte aus dem Nachlass (1898-1925). Dordrecht, the Netherlands: Springer.

Husserl, E. (1983). Ideas pertaining to a Pure Phenomenology and to a Phenomenological Philosophy: General Introduction to a Pure Phenomenology. (F. Kersten, Trans.). The Hague, the Netherlands: Martinus Nijhoff Publishers.

Husserl, E. (2012). Zur Lehre vom Wesen und zur Methode der eidetischen Variation: Texte aus dem Nachlass (1891-1935). Dordrecht, the Netherlands: Springer. 
Husserl, E. (2015). Phänomenologie und Erkenntnistheorie. Milan, Italy: BUR.

Ingarden, R. (Ed.). (1968). Briefe an Roman Ingarden: Mit Erläuterungen und Erinnerungen an Husserl. The Hague, the Netherlands: Martinus Nijhoff Publishers.

Kidd, I. J. (2017). Beauty, virtue and religious exemplars. Religious Studies, 53(2), 171-181.

Kind, A. (2013a). The Heterogeneity of the Imagination, Erkenntnis, 78, 141-159.

Kind, A. (2013b). How Imagination Gives Rise To Knowledge. In F. Macpherson \& F. Dorsch (Eds.), Perceptual Memory and Perceptual Imagination. Oxford, UK: Oxford University Press.

Kirk, R. (1981). The Moral imagination. Literature and Belief, 1, 37-49.

McRobie, H. (2014). Martha Nussbaum, empathy, and the moral imagination. Retrieved September 20, 2018 from https://www.opendemocracy.net

Nussbaum, M. C. (1995). Poetic Justice: The Literary Imagination and Public Life. Boston, MA: Beacon Press.

Sartre, J. P. (1940). L'imaginaire: Psychologie phénoménologique de l'imagination. Paris, France: Gallimard.

Scheler, M. (1911-1921). Vorbilder und Führer. In GW X (1957, 2000): Schriften aus dem Nachlaß, Bd. 1: Zur Ethik und Erkenntnislehre.

Scheler, M. (1973). Formalism in Ethics and Non-formal Ethics of Values: A New Attempt Toward the Foundation of an Ethical Personalism. (M. S. Frings \& R. L. Funk, Trans.). Evanston, IL: Northwestern University Press; Scheler, M.1913/16; 1927. Der Formalismus in der Ethik und die materiale Wertethik. In GW II (1954, 2009).

Scheler, M. (2013). Der Formalismus in der Ethik und die materiale Wertethik (1913/16; 1927). Milan, Italy: Bompiani.

Tolstoy, L. (2000). Resurrection (L. Maude, Trans.). The Pennsylvania State University: Penn State Electronic Classics Series Publication.

Williamson, T. (2016). Knowing by Imagining. In A. Kind \& P. Kung (Eds.), Knowledge Through Imagination (pp. 113-123). Oxford, UK: Oxford University Press.

Zagzebski, L. (2017). Exemplarist Moral Theory. Oxford, UK: Oxford University Press. 